\title{
Diyabet Hastalarının Covid-19 Salgınıyla İlgili Endişelerinin ve Bakım İhtiyaçlarının Belirlenmesi
}

\author{
Esra SARAÇOĞLU ${ }^{1}$ ๑ 凶, İlknur AYDIN AVCI ${ }^{2}$ (1) \\ ${ }^{1}$ SBÜ Samsun Eğitim ve Araştırma Hastanesi, Sağlık Turizmi Birimi, Samsun, Türkiye \\ ${ }^{2}$ Ondokuz Mayıs Üniversitesi, Sağlık Bilimleri Fakültesi, Samsun, Türkiye \\ Bu makaleye yapılacak atıf: Saraçoğlu E ve Aydın Avcı İ. Diyabet Hastalarının Covid-19 Salgınıyla İlgili Endişelerinin ve Bakım İhtiyaçlarının Belirlenmesi. \\ Turk J Diab Obes 2021;2: 202-209.
}

\begin{abstract}
ÖZ
Amaç: Bu çalışmayla diyabet hastalarının Covid-19 salgını ile ilgili endişelerini ve bakım ihtiyaçlarını belirlemek amaçlanmıştır.

Gereç ve Yöntemler: Tanımlayıcı türdeki çalışmanın evrenini Türkiye’de yaşayan diyabet hastaları oluşturmaktadır. Veriler araştırmacılar tarafından literatür doğrultusunda oluşturulan çevrimiçi soru formu ile sosyal medya platformu Facebook aracılığı ile toplanmıştır. Çalışmaya katılmaya istekli 213 diyabet hastası örneklemi oluşturmuştur. Verilerin değerlendirilmesinde tanımlayıcı istatistik testleri kullanılmıştır. Çalışmaya başlamadan önce Sağlık Bakanlığı’ndan çalışma izni alındıktan sonra etik kurul onayı alınmıştır.

Bulgular: Katılımcıların \%61,5 kadın, \%43,7’si "5-10 yıl arasında” diyabet hastası ve yaş ortalaması 55,12 $\pm 12,79$ olarak belirlenmiştir. Covid-19 salgını sürecinde katılımcıların; \%69,0’ı hastaneye doktor kontrolüne gidemediğini ve \%85’i virüsten korunmak için maske taktı̆̆ını belirtmiştir. Katılımcıların \%82,6’sı Covid-19'la ilgili haberleri televizyondan takip ettiklerini bildirmiştir. Covid-19 salgını sürecinde diyabet hastalarının en fazla gereksinim duydukları bakım ihtiyaçları; kan şekeri kontrolü, diyete uyum, fazla dışarı çıkamadıkları için evde düzenli egzersiz yapamama $(\% 46,5)$, salgından diyabet hastalarının nasıl etkileneceği hakkında bilgi sahibi olma (\%61,5), diğer diyabet hastalarının bu süreçte neler yaptığını bilmek isteme $(\% 53,1)$, bu süreçte sağlık personelinden tavsiyeler almak isteme $(\% 77,9)$ olarak belirlenmiştir. Salgın sürecindeki en fazla endişeleri; virüsün kendilerine bulaşma ihtimali $(\% 68,1)$, virüsün kendilerini hasta etme ihtimali (\%68,1) ve virüs nedeniyle ölmektir (\%69).

Sonuç: Sonuç olarak Covid-19 pandemi sürecinde yüksek riskli grup olarak değerlendirilen diyabet hastalarının endişe ve bakım ihtiyaçlarının giderilmesi için sağlık kurumlarında diyabet destek masaları, telefon danışma hatları gibi birimler oluşturulması önerilebilir.
\end{abstract}

Anahtar Sözcükler: Diyabet, Covid-19, Pandemi, Bakım ihtiyaçları, Endişe

\section{Determination of the Diabetes Patients Concerns and Care Needs About the Covid-19 Pandemic}

\begin{abstract}
Aim: The purpose of this study is to identify the COVID-19 epidemic concerns and care needs of diabetes patients.

Material and Methods: This descriptive study was conducted with diabetes patients constitutes living in Turkey. The data were collected on the social media platform Facebook, with an online questionnaire created by the researchers in line with the literature.The sample of the study consisted of 213 diabetic patients who were willing to participate in the study. Descriptive statistical tests were used to evaluate the data. Before starting the study, ethics committee approval was obtained after the study permission was obtained from the Ministry of Health.

Results: The participants, $61.5 \%$ were women, $43.7 \%$ had diabetes "between 5 - 10 years" and their mean age was $55.12 \pm 12.79$. In the process of the Covid-19 outbreak, the participants; $69.0 \%$ could not go to the hospital for medical examination and to be protected from

ORCID: Esra Saraçoğlu / 0000-0003-3808-1531, İlknur Aydın Avcı / 0000-0002-5379-3038


viruses $85 \%$ stated that they wore masks. $82,6 \%$ of the participants stated that they followed the news about Covid-19 on television. The most important care needs of diabetes patients during the Covid-19 outbreak determined as; blood sugar control, compliance with diet, not being able to exercise regularly at home because they cannot go out too much (46.5\%), having information about how diabetic patients will be affected by the epidemic (61.5\%), wanting to know what other diabetic patients do in this process (53.1\%), asking for advice from health care personnel during this process (77.9\%). The most concern of diabetes patients during the epidemic process are; the probability of the virus infecting them $(68.1 \%)$, the probability of the virus making them sick (68.1\%), and dying due to the virus (69\%).

Conclusion: As a result, it may be suggested to establish units such as diabetes support desks and telephone counseling lines in health institutions to address the concerns and care needs of diabetes patients who are considered to be a high-risk group during the Covid-19 pandemic process.

Keywords: Diabetes, Covid-19, Pandemic, Care needs, Worries

\section{GİRIŞ}

Koronavirüs hastalığı farklı şiddetlerde hastalık yapma özelliğine sahip olan Çin, Wuhan'da ilk tespit edildiğinden bu zamana kadar tüm dünyaya hızla yayılmış bir pandemidir(1). Dünya Sağlık Örgütü; altıncı halk sağlığı acil durumu olarak Covid-19'u pandemi olarak Mart 2020'de ilan etmiştir (2). Bulaşıcı hastalıklarda, halk sağlığı acil durumunun erken evresinde antiviral ilaçlar ve aşılar olmadan izolasyon, karantina, sosyal mesafe ve toplumu kontrol altına alma gibi klasik halk sağlığı önlemleri, salgını kontrol altına almak için en iyi ve en yaygın yaklaşımlardandır (3). Alınan bu önlemler her birey gibi diyabet hastalarının yaşam tarzlarını, psikolojilerini ve kan şekerlerini olumsuz etkileyebilir (4).

Covid-19 hastalığında mortalite oranı yüksek olmamasına rağmen (5), diyabetli olma; hastalı̆̆ın şiddeti, akut solunum sıkıntısı sendromu ve artan mortalite ile ilişkili ayırt edici bir komorbidite olarak ortaya çıkmıştır (6). Diyabet hastalarının özellikle influenza ve pnömoni için artmış enfeksiyon riskine sahip olduğu iyi bilinmektedir. Yapılan epidemiyolojik çalışmalar Covid-19'un ciddiyetini etkileyen en önemli komorbiditelerden biri olarak diyabeti işaret etmiştir (7). Glikoz metabolizması bozukluğuyla kendini gösteren kronik bir hastalık olan diyabet, özellikle yaşlı popülasyonda mevcut toplumun en hizlı büyüyen sağlık sorunlarından biridir (8).Yapılan bir çalışmada; Covid-19 tanısı ile hastaneye yatırılan diyabetlilerde; beden kitle indeksi, uzun süreli glikoz kontrolü ve trakeal entübasyon pozitif ve bağımsız şekilde yedi gün içinde ölümle ilişkilendirilmiştir (7).

Tüm dünya için yeni bir hastalık olan Covid-19'un diyabetlilerde enfeksiyon geliştirme riskini artırdığı varsayılmaktadır. Diyabetle birlikte ileri yaş, kalp hastalığı, böbrek hastalığı ve diğer ek hastalıkların varolması hastalığın ciddiyetinin daha da artmasına neden olmaktadır. Hastalar için; iyi bir glisemik kontrolü sürdürmeleri enfeksiyon riskini ve hastalığın ciddiyetini azaltmaya yardımcı olabileceği için önemlidir. Buna bağlı olarak hastalarda kan şekeri seviye- lerinin daha sık izlenmesi (kendi kendine kan şekeri takibi) gereklidir. İyi glisemik kontrolün, aşırı bakteriyel pnömoni olasılığını azaltabileceği düşünülmektedir (9).

Diyabetin Covid-19 hastalığının kötü ilerlemesi (mekanik ventilasyon ihtiyacı veya yoğun bakım ünitesine kabul ve nihayetinde ölüm) ve akut solunum sıkıntısı sendromu gelişimi için bir risk faktörü olduğunu gösteren birçok kanıt mevcuttur (10-14).

Covid-19 pandemisi sırasında Çin'de yapılan bir çalışmada; Tip2 diyabetlilerin glisemik kontrollerinde (yüksek açlık kan şekeri) kötüleşme yaşadıkları belirtilmiştir (4). Sosyal mesafe, karantina ve tam kapanmanın etkisi olarak sosyal yaşam tarzındaki değişiklikler, kötü glukoz kontrolüne neden olabilmektedir. Bu durumun ilk nedeni olarak; sosyal mesafe ve kapanma diyabetlilerin fiziksel aktivitelerini s1nırlandırabilir. Kapanma ile diyabetlilerin daha önce iyi glisemik kontrolle ilişkilendirilen beslenme alışkanlıkları, gıda arzındaki sınırlılık nedeniyle değişebilir. Devam eden kısıtlamalar hastaların ilaç ve şeker striplerini temin etmede zorluk yaşamasına neden olabilir. Son olarak; diyabetlilerin rutin doktor kontrollerine gitmesi ve ilaç dozlarının ayarlanması mümkün olamayabilir (6).

Covid-19 dünyanın her yerinde, insanların psikolojilerini olumsuz etkilemiştir. Virüse yakalanmanın sürekli kaygısı, odalarda kilitli kalmanın stresi, yakınları ve sevdikleriyle buluşamama stresi insanların psikolojilerini önemli ölçüde etkilemiştir. Salgınla ilgili ani ve sürekli değişen devamlı haber akışı, herkesi endişelendirmektedir (15).

Diyabetli kişilerin yaklaşı \%40'ının, genel popülasyonla karşılaştırıldığında, depresyon, anksiyete, yeme bozuklukları ve stres gibi bir dizi psikososyal sorunun yaygınlığında artış yaşadığı bilinmektedir (16). Diyabetliler, salgın sırasında depresyon ve anksiyete gibi çeşitli derecelerde olumsuz duygulara sahip olma eğilimindedir. Bu gibi duygular Covid-19 pandemisi sürecinde diyabetli kişilerin glisemik kontrolünü etkileyebilmektedir (6). Çin'de 1210 katılımcıyla salgın sıra- 
sında yapılan bir çalışmada, katılımcıların yarısının salgının psikolojik etkisini, orta veya şiddetli olarak derecelendirdiği bulunmuştur. Aynı çalışmada kronik hastalığı olan kişilerin, kronik hastalığ 1 olmayanlara kıyasla daha fazla stres, anksiyete ve depresyon yaşadığı belirlenmiştir (17).

Literatürde Covid-19 salgının sağlık üzerine etkileri hakkında pek çok çalışma olmasına rağmen, diyabetliler üzerine etkisi hakkında sınırlı sayıda çalışmaya rastlanmıştır. Bu nedenle; Covid-19 salgını sırasında diyabet hastalarının salgınla ilgili endişelerini ve bakım ihtiyaçlarını belirlemek amacıyla bu çalışma planlanmıştır.

\section{GEREÇ ve YÖNTEMLER}

\section{Araștırmanın Şekli}

$\mathrm{Bu}$ çalışma tanımlayıcı araştırma ilkelerine uygun olarak gerçekleştirilmiştir.

\section{Araştırmanın Yapıldığı Yer ve Zaman}

Bu çalışma; Eylül 2020 tarihinde sosyal medya platformu Facebook aracılığı ile diyabet hastalarıyla yapılmıştır.

\section{Araștırmanın Evren ve Örneklemi}

Araştırmanın evrenini Türkiye'de yaşayan, sosyal medya platformu Facabook'ta 7000 üyeye sahip, sadece diyabet hastalarının oluşturduğu kapalı bir grup oluşturmaktadır. Bilinen grupta anksiyete oranı $\% 78$ olarak alındığında \%95 güven aralığı, \%5 hata payı ve \%80 örnek gücü ile araştırmaya alınması gereken diyabetli hasta sayısı 148 olarak bulunmuştur. Araştırmaya 213 diyabetli hasta katılmış olup, post hocpower analizinde örneklem gücü $\% 98$ olarak hesaplanmiştır.

\section{Verilerin Toplanması}

Araştırma ile ilgili sosyal medya platformu Facebook'ta 7000 diyabet hastasının üyesi olduğu kapalı bir grupta duyuru yapılmıştır. Soru formu Google.form üzerinden düzenlenerek Facebook'ta bu grupta Eylül 2020 tarihinde 15 gün süreyle çevrimiçi olarak paylaşılmıştır. Araştırma olasılıksız olarak çalışmaya katılan 213 kişi ile tamamlanmıştır.

\section{Veri Toplama Aracı}

Veri toplama aracı olarak; araştırmacılar tarafindan literatür incelenerek oluşturulan kişisel bilgi formu ve Covid-19 ile ilgili soru formu kullanılmıştır $(6,18,19)$. Covid-19 soru formu 33 maddeden oluşmaktadır ve katılımcılardan ifadelere "evet", "hayır" ve "biraz" cevaplarından birini vermesi istenmiştir. Soru formunun uygunluğu için uzman görüşü alınmıştır. Çevrimiçi anketle demografik verileri, diyabet hastalığ 1 ile ilgili verileri, Covid-19 salgını sürecindeki gereksinimleri, endişeleri, ihtiyaçları ve Covid-19'dan korunma yöntemleri ile ilgili bilgiler toplanmıştır.

\section{Araștırmanın Etik Yönü}

Araştırmanın yapılabilmesi için T.C. Sağlık Bakanlığı Bilimsel Araştırma Platformu'ndan 2020-06-21T12_26_48 numaralı izin sonrası, OMÜ Sosyal ve Beşeri Bilimler Etik Kurul'undan 21.07.2020/466 tarih ve protokol numarası ile gerekli etik kurul onayı alınmıştır. Katılımcılar araştırmanın içeriği ve gizlilik ilkelerinden bahseden bilgilendirilmiş onam formunu okuyup onaylayarak çalışmaya dahil olmuşlardır. Araştırma boyunca Helsinki bildirgesinin tüm ilkelerine uyulmuştur.

\section{Araştırmanın Sınırlılığı}

Araştırmanın sınırlılığı belli bir zaman dilimi içinde sadece internet erişimi olan diyabet hastalarıyla yapılmasıdır.

\section{Verilerin Değerlendirilmesi}

Veriler SPSS İstatistik Paket Programı Sürüm 20.00 programı kullanılarak değerlendirilmiştir. Parametrik testlerde ortalama \pm standart sapma, non-parametrik testlerde medyan (minimum-maksimum) verilirken, kategorik verilerde frekans (n) ve yüzde (\%) verilmiştir.

\section{BULGULAR}

Araştırmaya toplam 213 diyabet hastası katılmıştır. Katılımcıların yaş ortalaması $55.12 \pm 12,79$ 'dur. Katılımcıların 131'inin (\%61,5) kadın, 93'ünün $(\% 43,7)$ diyabet hastalık süresi 5-10 yl arasında, 125 'inin $(\% 58,7)$ diyabete ek kronik hastalığı olduğu belirlenmiştir. Katılımcılardan 139'u $(\% 65,3)$ diyabet tedavisi için oral antidiyabetik kullandığını belirtmiştir (Tablo 1).

Araştırmaya katılan diyabet hastaları Covid-19 salgını s1rasinda; 147'si (\%69) hastaneye doktor kontrolüne gitme; 107 'si $(\% 50,2)$ egzersiz yapma; 107'si $(\% 50,2)$ arkadaşlarıyla/akrabalarıyla sohbet etme gereksinimleri olduğunu bildirmiştir (Tablo 2).

Covid-19 virüsünden korunmak için katılımcıların 181'i (\%85) maske taktığını, 108’i $(\% 50,7)$ ellerini yıkadığını, 79’u $(\% 37,1)$ sosyal mesafe kurallarına uyduğunu, 76 's $1 \% 35,7)$ kalabalıktan kaçındığını (market, pazar vb...), 23’ü (\%10,8) ailesi ile görüşmediğini, 106 'sı $(\% 49,8)$ eve misafir kabul etmediğini bildirmiştir (Şekil 1).

Katılımciların 176'sı $(\% 82,6)$ Covid-19 ile ilgili haberleri televizyondan takip ettiklerini ve sadece 9'u $(\% 4,2)$ virüsün kendilerine bulaşma ihtimalinden endişe duymadıklarını belirtmiștir. Katılımcıların 145'i $(\% 68,1)$ 'i virüsün kendilerine bulaşma ihtimalinden endişeli olduklarını; 145 'i $(\% 68,1)$ virüsün kendilerini hasta etme ihtimalinden çok korktuklarını; 147'si (\%69) virüs nedeniyle ölmekten korktuğunu ve 153 'ü $(\% 71,8)$ virüsle ilgili hastalık belirtilerini hissederse 112 'yi arayacağını belirtmiştir (Tablo 3). 
Katılımcıların 67'si $(\% 31,5)$ salgın sürecinde kan şekerlerini kontrol altında tutmakta zorlanmadığını; 67'si $(\% 39,9)$ bu süreci sorunsuz atlatmak için ailelerinin destek olduğunu ve bildirmiştir. Katılımcıların 135’i $(\% 63,4)$ virüsün diyabet hastalarını etkilemesiyle ilgili sorularını sağlık personeline sormanın onları rahatlatabileceğini ve 166 'sı $(\% 77,9)$ bu süreçte sağlik personelinden tavsiye almanın kendilerini rahatlatacağını belirtmiştir (Tablo 4).

Tablo 1: Diyabet hastalarının demografik bilgileri $(\mathrm{n}=213)$

\begin{tabular}{|c|c|}
\hline Yaş (yıl) Ort $\pm S S$ & $55.12 \pm 12,79$ \\
\hline \multicolumn{2}{|l|}{ Cinsiyet n (\%) } \\
\hline Erkek & $82(38,5)$ \\
\hline Kadın & $131(61,5)$ \\
\hline \multicolumn{2}{|c|}{ Diyabet hastalığı tanı süresi n (\%) } \\
\hline $1-5$ yıl arası & $72(33,8)$ \\
\hline $5-10$ yıl arası & $93(43,7)$ \\
\hline $10-15$ yıl arası & $33(15,5)$ \\
\hline 15 yıldan fazla & $15(7,0)$ \\
\hline \multicolumn{2}{|c|}{ Diyabetten başka ek hastalığı olma durumu n (\%) } \\
\hline Evet & $125(58,7)$ \\
\hline Hayır & $88(41,3)$ \\
\hline \multicolumn{2}{|c|}{ Mevcut olan ek hastalıklar n (\%) } \\
\hline Hipertansiyon & $68(31,9)$ \\
\hline Kalp Hastalıkları & $39(18,3)$ \\
\hline Nörolojik Hastalıklar & $26(12,2)$ \\
\hline Astım & $23(10,8)$ \\
\hline Psikiyatrik hastalıklar & $20(9,4)$ \\
\hline Böbrek hastalıkları & $13(6,1)$ \\
\hline Felç & $6(2,8)$ \\
\hline $\mathrm{KOAH}$ & $6(2,8)$ \\
\hline Kanser & $4(1,9)$ \\
\hline \multicolumn{2}{|l|}{ Diyabet tedavi türüi n (\%) } \\
\hline Oral antidiyabetik kullanımı & $139(65,3)$ \\
\hline İnsülin kullanımı & $71(33,3)$ \\
\hline Diyete uyum & $3(1,4)$ \\
\hline
\end{tabular}

\section{TARTIȘMA ve SONUÇ}

Diyabet hastalarının Covid-19 salgını ile ilgili endişeleri ve bakım ihtiyaçlarının belirlenmesi amaçlanan bu çalışmada, diyabetlilerin yaygın olarak endişeli olduğu belirlenmiştir. En fazla endişe duydukları ifade; virüs nedeniyle ölmekten korkma (\%69), virüsün kendilerine bulaşma ihtimali $(\% 68,1)$, virüsün kendilerini hasta etme ihtimali $(\% 68,1)$, hastalıktan kurtulamayacağını düşünme $(\% 56,3)$ olarak belirlenmiştir. Danimarka'da 1396 diyabetliyle yapılan bir çalışmada, katılımcılar Covid-19 ile enfekte olursa diyabet nedeniyle aşırı etkilenmekten (\%56) endişelendiklerini bildirmişlerdir (18). Hastalığın ölüm oranı yüksek olmasa da kronik hastaları daha fazla etkilediğinin hastalar tarafından bilinmesi endişeye yol açmaktadır diye düşünülebilir.

Bu çalışmada katılımcıların yarısından fazlası diyabet ilaçlarını düzenli olarak kullandıklarını belirtmelerine rağmen; salgindan dolayı \%69'unun hastaneye doktor kontrollerine gidemedikleri tespit edilmiştir. Brezilya'da diyabet hastalarıyla yapılan bir çalışmada doktor kontrollerinin ve laboratuvar testlerinin ertelenmesinin hastaların kan şekerinde bozulmayla ilişkili olduğu belirtilmiştir (20). Salgın döneminde Türkiye'de Covid-19 salgın önlemleri arasında; hastanelerin Covid-19'la enfekte hastalara hizmette öncelik vermesi, diğer hastalar için poliklinik hizmetlerinin azaltılması, sadece acil ameliyatların yapılması, randevu alınmadan hasta muayene edilmemesi gibi bazı önlemler diyabet hastalarının rutin doktor kontrollerini aksatmasına neden olmuştur diye düşünülebilir (21). Ayrıca diyabet gibi kronik hastalığ ${ }_{1}$ olan, raporlu ilaç kullanması gereken hastaların ilaca erişiminin devamlılığını sağlamak için hastalara eczaneden reçetesiz ilaç temin edilmiştir (22). Salgınla mücadele kapsamında alınan bu önlemler hastaların hastane kontrollerine gitmesinin önünde engel teşkil ettiği düşünülebilir.

$\mathrm{Bu}$ çalışmada katılımcılar; "diyabet hastası olduğum için yüksek risk altında olduğumu biliyorum" $(\% 58,2)$ ve "televizyonda sürekli diyabet hastalarının risk altında olduğunun tekrarlanması beni endişelendiriyor" $(\% 52,6)$ ifadelerine yüksek oranda "evet" cevabını vermişlerdir. Diyabetli tüm insanların Covid-19 salgınında, diyabet tipi, diyabet

Tablo 2: Diyabet hastalarının salgın sırasındaki gereksinimleri

\begin{tabular}{lcc}
\hline & Var & Yok \\
\hline & $\mathbf{n ~ ( \% )}$ & $\mathbf{n ~ ( \% )}$ \\
\hline 1. Hastaneye doktor kontrolüne gitme gereksinimi & $\mathbf{1 4 7 ( 6 9 , 0 )}$ & $66(31,0)$ \\
\hline 2. İlaçlarınızı temin etme gereksinimi & $71(33,3)$ & $142(66,7)$ \\
\hline 3. Kendiniz için gerekli yiyecek, içecek temin etme gereksinimi & $66(31,0)$ & $147(69,0)$ \\
\hline 4. Egzersiz yapma gereksinimi & $107(50,2)$ & $106(49,8)$ \\
\hline 5. Arkadaşlarınızla/ akrabalarınızla sohbet etme gereksinimi & $107(50,2)$ & $106(49,8)$ \\
\hline
\end{tabular}


Tablo 3: Diyabet hastalarının Covid-19 salgını dönemindeki endişeleri

\begin{tabular}{|c|c|c|c|}
\hline & Var & Yok & Biraz \\
\hline & n (\%) & n (\%) & n (\%) \\
\hline 1. Diyabet hastası olduğum için yüksek risk altında olduğumu biliyorum. & $124(58,2)$ & $17(8,0)$ & $17(8,0)$ \\
\hline 2. Virüsün bana bulaşma ihtimali beni endişelendiriyor. & $145(68,1)$ & $9(4,2)$ & $59(27,7)$ \\
\hline 3. Salgın sürecini hasta olmadan atlatabileceğimi düşünüyorum. & $45(21,1)$ & $87(40,8)$ & $81(38,0)$ \\
\hline 4. Diyabet hastası olduğum için önlemlere tam olarak uymaya çalışıyorum. & $109(51,2)$ & $4(1,9)$ & $100(46,9)$ \\
\hline 5. Virüsün beni hasta etme ihtimali beni çok korkutuyor. & $145(68,1)$ & $5(2,3)$ & $63(29,6)$ \\
\hline 6. Virüsün bana bulaşma ihtimalini düşündüğümde elim ayağım titriyor. & $42(19,7)$ & $94(44,1)$ & $77(36,2)$ \\
\hline 7. Virüsün bana bulaşma ihtimalini düşündüğümde uykularım kaçıyor. & $38(17,8)$ & $121(56,8)$ & $54(25,4)$ \\
\hline 8. Salgın sürecinde uykusuzluk problemi yaşıyorum. & $40(18,8)$ & $124(58,2)$ & $49(23,0)$ \\
\hline 9. Virüs nedeniyle ölmek beni korkutuyor. & $147(69,0)$ & $10(4,7)$ & $56(26,3)$ \\
\hline $\begin{array}{l}\text { 10.Televizyonda sürekli diyabet hastalarının risk altında olduğunun tekrarlanması } \\
\text { beni endişelendiriyor. }\end{array}$ & $112(52,6)$ & $27(12,7)$ & $74(34,7)$ \\
\hline 11. Virüsle ilgili haberlerle artık ilgilenmiyorum. & $25(11,7)$ & $97(45,5)$ & $91(42,7)$ \\
\hline 12.Ne yaparsam yapayım virüsün bana bulaşacağını düşünüyorum. & $126(59,2)$ & $11(5,2)$ & $76(35,7)$ \\
\hline 13.Virüsün bana bulaşma ihtimali ile baş etmek beni psikolojik olarak zorluyor. & $57(26,8)$ & $78(36,6)$ & $78(36,6)$ \\
\hline 14.Virüs bana bulaşırsa, bu hastalıktan kurtulamayacağımı düşünüyorum. & $120(56,3)$ & $22(10,3)$ & $71(33,3)$ \\
\hline 15.Eğer kendimde virüse bağlı hastalık belirtilerini fark edersem 112 yi ararım & $153(71,8)$ & $14(6,6)$ & $46(21,6)$ \\
\hline $\begin{array}{l}\text { 16. Diyabet hastası olduğum için bulaşma riskine karşı söylenen bütün kurallara } \\
\text { uyuyorum. }\end{array}$ & $105(49,3)$ & $6(2,8)$ & $102(47,9)$ \\
\hline
\end{tabular}

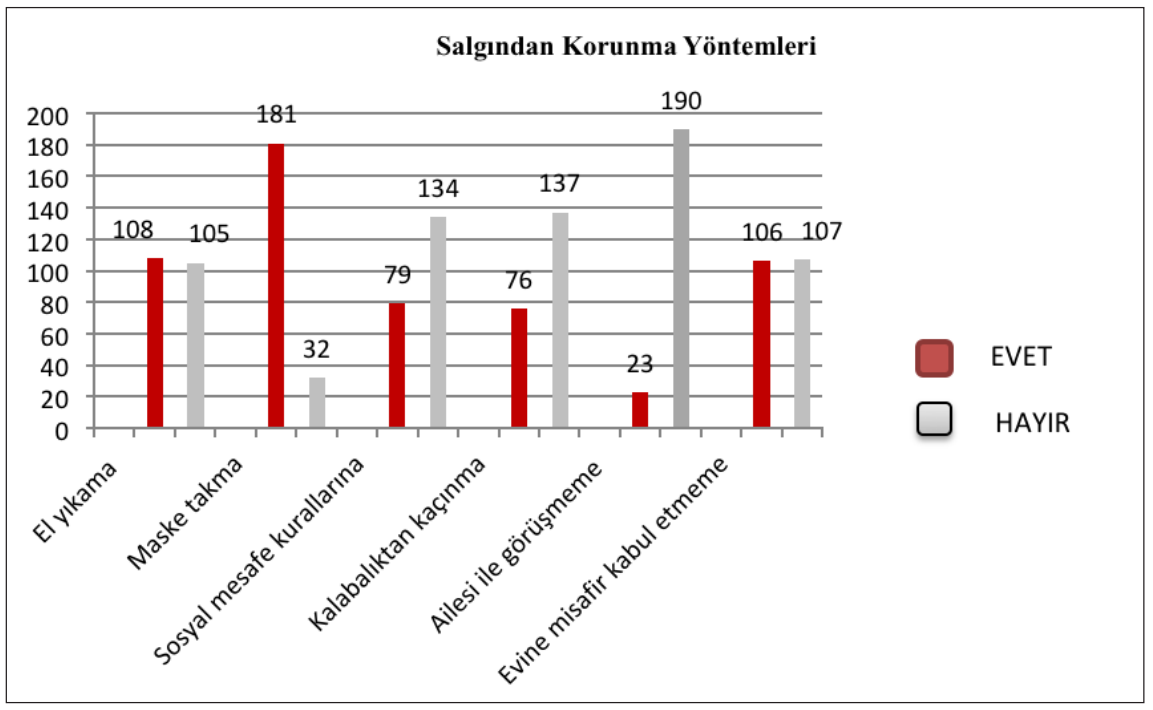

Şekil 1. Diyabet hastalarının salgından korunma yöntemleri hakkındaki uygulamaları kontrolü, diyabet komplikasyonu ne olursa olsun yüksek risk altında olduğunun bildirilmesi, bilgi eksikliğinin yanı sıra endişelerinin de artmasına neden olacağı belirtilmiştir (18). Çalışmanın sonuçları açıklanan bu ifade doğrultusundandir.

Bu çalışmada katılımcıların sadece \%33,8 sık sık kan şekeri kontrolü yaptığını, yarısından fazlası salgın sürecinde kan şekerini kontrol altında tutmakta zorlandığını (evet: \%27,7biraz: \%40,8), \%39'u bu süreçte diyetine uyduğunu, \%39,9’u salgın sürecini sorunsuz atlatmak için ailesinin destek oldu- ğunu ifade etmiştir. Yapılan bir çalışmada da bu çalışmaya benzer olarak katılımcıların \%12,04'ü son yedi gün içinde bir kez kan şekerini kontrol ettiğini bildirmiştir (23). Sağlıklı bir diyeti, düzenli egzersiz ve sağlıklı uyku düzenini içeren iyi bir yaşam tarzının, diyabet ile ilgili komplikasyonları önlemeye yardımcı olan iyi bir bağışıklık ve glisemik kontrole sahip olmak için önemli olduğu belirtilmiştir. Diyabet hastalığında günlük bakımın büyük bir kısmı hastalar ve aileleri tarafından gerçekleştirildiğinden, kendi kendine diyabet bakımı önemlidir ve bu bir dizi aktiviteyi 
Tablo 4: Diyabet hastalarının Covid-19 salgını dönemindeki ihtiyaçları

\begin{tabular}{|c|c|c|c|}
\hline & Var & Yok & Biraz \\
\hline & $\mathrm{n}(\%)$ & $\mathrm{n}(\%)$ & $\mathrm{n}(\%)$ \\
\hline 1. Salgın sürecinde sık sık şeker kontrolümü yapıyorum. & $72(33,8)$ & $65(30,5)$ & $76(35,7)$ \\
\hline 2. Salgın sürecinde şekerim bazen çok yükseliyor. & $62(29,1)$ & $66(31,0)$ & $85(39,9)$ \\
\hline 3. Salgın sürecinde şekerim bazen çok düşüyor. & $50(23,5)$ & $89(41,8)$ & $74(34,7)$ \\
\hline 4. Salgın sürecinde şekerimi kontrol altında tutmakta zorlanıyorum. & $59(27,7)$ & $67(31,5)$ & $87(40,8)$ \\
\hline 5. Salgın sürecinde ilaçlarımı düzenli kullanmaya çalışıyorum. & $154(72,3)$ & $5(2,3)$ & $54(25,4)$ \\
\hline 6. Salgın sürecinde diyetime uyuyorum. & $83(39,0)$ & $35(16,4)$ & $95(44,6)$ \\
\hline 7. Salgın sürecinde yeterli su içiyorum. & $80(37,6)$ & $53(24,9)$ & $80(37,6)$ \\
\hline 8. Ailem bu süreci sorunsuz atlatmam için bana destek oluyor. & $85(39,9)$ & $56(26,3)$ & $72(33,8)$ \\
\hline $\begin{array}{l}\text { 9. Virüs nedeniyle fazla dışarı çıkamadığım için evde düzenli egzersizlerimi } \\
\text { yapıyorum. }\end{array}$ & $32(15,0)$ & $99(46,5)$ & $82(38,5)$ \\
\hline $\begin{array}{l}\text { 10. Salgın sürecinde diyabet hastalarının nasıl etkileneceği hakkında bilgi sahibi } \\
\text { değilim. }\end{array}$ & $101(47,4)$ & $44(20,7)$ & $68(31,9)$ \\
\hline 11. Diyabet hastası olarak virüsle ilgili daha fazla bilgi sahibi olmak istiyorum. & $131(61,5)$ & $10(4,7)$ & $72(33,8)$ \\
\hline 12. Virüsün diyabet hastalarını etkilemesiyle ilgili sorularım var. & $90(42,3)$ & $35(16,4)$ & $88(41,3)$ \\
\hline $\begin{array}{l}\text { 13. Virüsün diyabet hastalarını etkilemesiyle ilgili sorularımı sağlık personeline } \\
\text { sormak beni rahatlatabilir. }\end{array}$ & $135(63,4)$ & $3(1,4)$ & $75(35,2)$ \\
\hline $\begin{array}{l}\text { 14. Virüs bana bulaşır diye diyabet hastalığımla ilgili kontrollerim için hastaneye } \\
\text { gitmiyorum. }\end{array}$ & $98(46,0)$ & $28(13,1)$ & $87(40,8)$ \\
\hline 15. Virüsün hastalık belirtilerini biliyorum. & $166(77,9)$ & $1(0,5)$ & $46(21,6)$ \\
\hline $\begin{array}{l}\text { 16. Diğer diyabet hastalarının virüs sürecinde neler yaptı̆̆ını bilmek beni } \\
\text { rahatlatabilir. }\end{array}$ & $113(53,1)$ & $17(8,0)$ & $83(39,0)$ \\
\hline 17. Bu süreçte sağlık personelinden tavsiyeler almak beni rahatlatabilir. & $166(77,9)$ & $0(0,0)$ & $47(22,1)$ \\
\hline
\end{tabular}

içermektedir (örneğin, kan şekerini kendi kendine izleme, sağlıklı yemek yeme,düzenli fiziksel egzersiz ve ayaklarını kontrol etme gibi) (23). Bu çalışmada; diyabet hastalarının kendi kendilerine diyabet yönetimlerinin salgınla birlikte etkilendiği belirlenmiştir. Salgın hastalık sürecinde, kısıtlama zamanlarında aileyle birlikte daha fazla zaman geçiren diyabet hastalarının aile üyelerine ve diyabet hastalarına bu konunun önemi hakkında gerekli diyabet eğitimi verilerek diyabetlinin kontrolü daha yakından takip edilebilir diye düşünülmektedir.

Katılımcıların \%39'u diyetine uyduklarını ifade etmiştir. Gosh ve ark (2020) Hindistan'da 150 diyabetliyle yaptığı bir çalışmada, katılımcıların \%56'sı aynı miktarda yemek yediklerini ifade etmelerine rağmen, \%21'i karbonhidrat tüketiminde artış, \%13'ü yağ tüketiminde artış, \%20'si meyve tüketiminde artış, \%20'si atıştırma sıklığında artış bildirmiştir (24). Polonyalı yetişkinlerle yapılan bir çalışmada, kısıtlama sirasinda yumurta, patates, tatli, konserve et ve alkolün önemli ölçüde daha yaygın olarak tüketildiği, günlük tatlı ve konserve et porsiyonlarının sayısının önemli ölçüde arttığı ve katılımcıların $\% 45,86$ 'sı aşırı kilolu olmak üzere vücut ağırlı̆̆ında değiş̧iklik olduğunu bildirmiştir (25). Salgın döneminde evde kalma süresinin uzaması, evde yapılacak aktivitelerdeki kısıtlılık ve dişarı çıkamamanın insanların yeme alışkanlıklarını etkilediği düşünülebilir. Yeme alışkanlıklarındaki bu değişiklik diyabet hastasının kan şekeri yönetimini de etkileyebilir.

Bu çalışmada katılımcıların \%15’i evde düzenli egzersiz yaptıklarını bildirmiştir. Yapılan bir çalışmada; katılımcıların yarısının (\%50) fiziksel olarak aktif olduğu bulunmuştur (23). Bir çalışmada da, hastaların \%62'sinin bazı egzersiz türlerini takip ettiğini (24), başka bir çalışma da katılımcıların \%80'inin egzersizlerini düzenli yaptıklarını göstermiştir (19). Karantina sırasında katılımcıların \%61'inin fiziksel aktivite yaptığı başka bir çalışmada da benzer sonuçlar bulunmuştur (26). Bu çalışma diğer çalışmalarla benzerlik göstermemektedir. Fiziksel aktivite depresyon ve anksiyete bozukluklarının tedavisinde de kullanılan önemli bir halk sağlığı aracı olduğu için glisemik kontrolün yanı sıra diyabetlilerin psikolojik iyilikleri için de önemlidir (27). Covid-19 pandemisine yönelik kısıtlama önlemleri, her tür fiziksel aktivitenin ortadan kaldırılması gerektiği anlamına gelmemektedir. Güvenli, basit ve kolayca uygulanabilen iç mekân egzersizleri (örn. vücut ağırlığı egzersizi, ip atlama, 
yoga, vb.), sosyal mesafeyi korurken zindelik düzeylerini korumaya yardımcı olabilir (28). Düzenli fiziksel egzersizin bir yaşam biçimi olduğu düşünüldüğünde çalışma yapılan ülkelerin farklı olması, katılımcıların kültürel farklılıklarının yansıması olarak sonuçlardaki bu farklılığın ortaya çıktığ düşünülebilir.

Covid-19 şu anda dünyadaki en endişe verici hastalıklardan biridir (29). Salgın döneminde hastanelerin kaynaklarını kullanmak için normal işleyişlerini değiştirmek zorunda kalması, kronik tıbbi sorunları ve ağrıları yeterince tedavi edilemeyen yaşl yetișkinleri etkilemektedir. Bu etkilenme sadece yaşam kalitesiyle ilgili olmayıp aynı zamanda altta yatan kayg1 ve depresyonu da tetikleyebilir. İzolasyon normal zamanlarda bile yetişkinler için bir halk sağlığı sorunudur. Salgınla birlikte uzun süreli izolasyon yetişkin yaş grubunu hem duygusal hem de tıbbi açıdan risk altında bırakabilir (30). Katılımciların \%69'u Covid-19 nedeniyle ölmekten korktuklarını, $\% 68,1$ 'i virüsün kendilerine bulaşma ihtimalinden dolayı endişelendiklerini, $\% 68,1$ virüsün kendisini hasta etme ihtimalinden çok korktuklarını, \%59,2'si önlem almalarına rağmen virüsün kendilerine bulaşacağını düşünmektedir. Bu çalışmada katılımcıların endişe alanları yüksek oranda ölüm korkusu ve hasta olma ihtimali ile ilgilidir.

Bu çalışmada katılımcıların büyük çoğunluğu $(\% 77,9)$ sağlık personelinden tavsiyeler almanın kendilerini rahatlatabileceğini ifade etmiştir. Yapılan bir çalışmada diyabet hastalarının birinci basamak hekimlerine duydukları güvenin düşük depresyon ve anksiyete seviyeleri ile ilişkili oluğu belirlenmiştir (31). Bu çalışma sonucunda diyabet hastalarının salgın döneminde gerekli doğru bilgiye ulaşmak ve mevcut durumları hakkında tavsiye almak için sağlık personeline ihtiyaç duyduğu belirlenmiştir. Gerekli girişimler planlanarak diyabetlilerin bu ihtiyacının karşılanmasının hastaları rahatlatacağı düşünülmektedir.

Sonuç olarak, tüm dünyayı etkisi altına alan Covid-19 pandemi sürecinde yüksek riskli grup olarak değerlendirilen diyabet hastalarının çoğunluğunun ilaçlarını düzenli kullandıkları, virüs bulaşmasına karşı önlemlere uydukları hâlde virüsün bulaşması ve kendilerini hasta etme konusunda yüksek oranda endişeleri olduğu ve virüs nedeniyle ölmekten korktukları belirlenmiştir. Bu süreçte sağlık personeliyle iletişim hâlinde olmak onları daha güvende hissettirebilir. Diyabet hastalarının endişe ve bakım ihtiyaçlarını gidermek için sağlık profesyonelleriyle iletişimlerini ve diyabet kontrollerinin devamlılığını sağlamak için sağlık kurumlarında diyabet destek masaları, diyabet hastaları için telefon danıșma hatları gibi birimler oluşturulması önerilebilir. Diyabet gibi kronik hastalığa sahip hastalar için gerekli önlemler alınmaz, salgın döneminde tedavi ve kontrollerinin devamlılığı sağlanmazsa salgın bittikten sonra bu hastaların sağ- lık hizmetlerine daha büyük yük olacağı düşünülmektedir. Diyabet hastalığına bağlı gelişebilecek kısa ve uzun dönem komplikasyonların diyabet hastalarının yaşam kalitesini azaltması da önlem alınmasının başka bir gerekliliğidir.

Daha ileri boyutlu ve kapsamlı çalışmalarla diyabet hastaları hakkında sistematik veri toplanarak salgın hastalık dönemlerinde ihtiyaçları ve diyabetlerini daha iyi yönetebilmeleri için geliştirilebilecek uygun yöntemler belirlenebilir.

Teșekkür

Yok

Yazarların Makaleye Katkı Beyanı

Çalışma konusunun belirlenmesi ve çalışmanın düzenlenmesi: İlknur Aydın Avcı, Esra Saraçoğlu, Verilerin toplanması: Esra Saraçoğlu, Veri analizi ve yorumlama: Esra Saraçoğlu, Yazı taslağı: Esra Saraçoğlu, İçeriğin eleştirel incelenmesi: İlknur Aydın Avcı, Esra Saraçoğlu, Çalışmanın gözden geçirilmesi ve son onay: İlknur Aydın Avcı ve Esra Saraçoğlu.

Çıkar Çatışması

Yazarların beyan edecek herhangi bir çıkar çatışmaları yoktur.

Finansal Destek

Bu çalışmanın yapılabilmesi için herhangi bir finansal destek alınmamıştır.

\section{Etik Kurul Onayı}

Araştırma için T.C. Sağlık Bakanlığı Bilimsel Araştırma Platformu'ndan 2020-06-21T12_26_48 numaralı izin sonrası, OMÜ Sosyal ve Beşeri Bilimler Etik Kurul'undan 21.07.2020/466 tarih ve protokol numarası ile onay alınmıştır.

\section{Hakem Değerlendirmesi}

Kör hakemlik süreci yayınlanmaya uygun bulunmuş ve kabul edilmiştir.

\section{KAYNAKLAR}

1. Guan WJ, Ni ZY, Hu Y, Liang WH, Ou CQ, He JX, Liu L, Shan H, Lei CL, Hui DSC, Du B, Li LJ, Zeng G, Yuen KY, Chen RC, Tang CL, Wang T, Chen PY, Xiang J, Li SY, Wang JL, Liang ZJ, Peng YX, Wei L, Liu Y, Hu YH, Peng P, Wang JM, Liu JY, Chen Z, Li G, Zheng ZJ, Qiu SQ, Luo J, Ye CJ, Zhu SY, Zhong NS; China Medical Treatment Expert Group for Covid-19. Clinical Characteristics of Coronavirus Disease 2019 in China. N Engl J Med. 2020;382(18):1708-1720.

2. Web: www.eurosurveillance.org Erişim T: 02.01.2021

3. Wilder-Smith A, Freedman DO. Isolation, quarantine, social distancing and community containment: Pivotal role for oldstyle public health measures in the novel coronavirus (2019nCoV) outbreak. J Travel Med. 2020;27(2):1-4.

4. Xue T, Li Q, Zhang Q, Lin W, Wen J, Li L, Chen G. Blood glucose levels in elderly subjects with type 2 diabetes during COVID-19 outbreak: A retrospective study in a single center. medRxiv. 2020. 
5. Huang C, Wang Y, Li X, Ren L, Zhao J, Hu Y, Zhang L, Fan G, Xu J, Gu X, Cheng Z, Yu T, Xia J, Wei Y, Wu W, Xie X, Yin W, Li H, Liu M, Xiao Y, Gao H, Guo L, Xie J, Wang G, Jiang R, Gao Z, Jin Q, Wang J, Cao B. Clinical features of patients infected with 2019 novel coronavirus in Wuhan, China. Lancet. 2020;395(10223):497-506.

6. Banerjee M, Chakraborty S, Pal R. Diabetes self-management amid COVID-19 pandemic. Diabetes Metab Syndr Clin Res Rev. 2020;14(4):351-354.

7. Cariou B, Hadjadj S, Wargny M, Pichelin M, Al-Salameh A, Allix I, Amadou C, Arnault G, Baudoux F, Bauduceau B, Borot S, Bourgeon-Ghittori M, Bourron O, Boutoille D, CazenaveRoblot F, Chaumeil C, Cosson E, Coudol S, Darmon P, Disse E, Ducet-Boiffard A, Gaborit B, Joubert M, Kerlan V, Laviolle B, Marchand L, Meyer L, Potier L, Prevost G, Riveline JP, Robert R, Saulnier PJ, Sultan A, Thébaut JF, Thivolet C, Tramunt B, Vatier C, Roussel R, Gautier JF, Gourdy P; CORONADO investigators. Phenotypic characteristics and prognosis of inpatients with COVID-19 and diabetes: the CORONADO study. Diabetologia. 2020;63(8):1500-1515.

8. International Diabetes Federation. IDF Diabetes Atlas Ninth edition 2019 [Internet]. International Diabetes Federation. 2019. 176 p.

9. Gupta R, Ghosh A, Kumar A, Misra A. Clinical considerations for patients with diabetes in times of COVID-19 epidemic. Diabetes Metab Syndr Clin Res Rev. 2020;14(3):211-212.

10. Pugliese G, Vitale M, Resi V, Orsi E. Is diabetes mellitus a risk factor for CoronaVirus Disease 19 (COVID-19)? Acta Diabetol. 2020;57(11):1275-1285.

11. Wu J, Zhang J, Sun X, Wang L, Xu Y, Zhang Y, Liu X, Dong C. Influence of diabetes mellitus on the severity and fatality of SARS-CoV-2 (COVID-19) infection. Diabetes Obes Metab. 2020;22(10):1907-1914.

12. Yu B, Li C, Sun Y, Wang DW. Insulin treatment is associated with increased mortality in patients with COVID-19 and type 2 diabetes. Cell Metab. 2021;33(1):65-77.e2.

13. Pal R, Bhadada S. COVID-19 and diabetes: An unholy interaction of two pandemics. Diabetes Metab Syndr Clin Res Rev. 2020;14(January):513-517.

14. Varikasuvu SR, Dutt N, Thangappazham B, Varshney S. Diabetes and COVID-19: A pooled analysis related to disease severity and mortality. Prim Care Diabetes. 2021;15(1):24-27.

15. Organization WH. Mental health and psychosocial considerations during the COVID-19 outbreak [Internet]. 2020. Available from: https://www.who.int/docs/defaultsource/coronaviruse/mental-health-considerations.pdf

16. Young-Hyman D, De Groot M, Hill-Briggs F, Gonzalez JS, Hood K, Peyrot M. Psychosocial care for people with diabetes: A position statement of the American diabetes association. Diabetes Care. 2016;39(12):2126-2140.

17. Wang C, Pan R, Wan X, Tan Y, Xu L, Ho CS, Ho RC. Immediate Psychological Responses and Associated Factors during the Initial Stage of the 2019 Coronavirus Disease (COVID-19) Epidemic among the General Population in China. Environ Res Public Heal. 2020;113(5):311-312.
18. Joensen LE, Madsen KP, Holm L, Nielsen KA, Rod MH, Petersen AA, Rod NH, Willaing I. Diabetes and COVID-19: psychosocial consequences of the COVID-19 pandemic in people with diabetes in Denmark - what characterizes people with high levels of COVID-19-related worries? Diabet Med. 2020;37(7):1146-1154.

19. Nachimuthu S, Vijayalakshmi R, Sudha M, Viswanathan V. Coping with diabetes during the COVID -19 lockdown in India: Results of an online pilot survey. Diabetes Metab Syndr Clin Res Rev. 2020;14(4):579-582.

20. Thomaz M, Barone U, Bega S, Chaluppe M. Decentralized COVID-19 measures in Brazil were ineffective to protect people with diabetes. Diabetes Metab Syndr. 2020;14(6):19731978.

21. TC Sağlık Bakanlığı. COVID-19 Pandemisinde Sağlık Kurumlarında Çalışma Rehberi ve Enfeksiyon Kontrol Önlemleri. Ankara: TC Sağlık Bakanlığı, 14.Aralık.2020.

22. Web:https://www.titck.gov.tr/duyuru/eczacilara-ve-tumilgililere-duyurulur-16032020090441 Erişim T: 02.01.2021

23. Bala R, Srivastava A, Potsangbam T, Anal L, Ningthoujam GD. Self care practices and psychological distress among diabetic patients in Manipur during COVID-19: A scenario from the North East. Diabetes Metab Syndr Clin Res Rev. 2021;15(1):9398.

24. Ghosh A, Arora B, Gupta R, Anoop S, Misra A. Effects of nationwide lockdown during COVID-19 epidemic on lifestyle and other medical issues of patients with type 2 diabetes in north India. Diabetes Metab Syndr Clin Res Rev. 2020;14(5):917-920.

25. Błaszczyk-Bębenek E, Jagielski P, Bolesławska I, Jagielska A, Nitsch-Osuch A, Kawalec P. Nutrition behaviors in polish adults before and during COVID-19 lockdown. Nutrients. 2020;12(10):1-16.

26. Tornese G, Ceconi V, Monasta L, Carletti C, Faleschini E, Barbi E. Glycemic control in type 1 diabetes mellitus during COVID-19 quarantine and the role of in-home physical activity. Diabetes Technol Ther. 2020;22(6):462-467.

27. Peluso MAM, Guerra de Andrade LHS. Physical activity and mental health: The association between exercise and mood. Clinics (Sao Paulo). 2005;60(1):61-70.

28. Chen P, Mao L, Nassis GP, Harmer P, Ainsworth BE, Li F. Coronavirus disease (COVID-19): The need to maintain regular physical activity while taking precautions. J Sport Heal Sci. 2020;9(2):103-104.

29. Biswas A, Bhattacharjee U, Chakrabarti AK, Tewari DN, Banu H, Dutta S. Emergence of Novel Coronavirus and COVID-19: whether to stay or die out? Crit Rev Microbiol. 2020;46(2):182193.

30. Ishikawa RZ. I may never see the ocean again: loss and grief among older adults during the COVID-19 pandemic. Psychol Trauma. 2020;Agu12(1):85-86.

31. AlRuthia Y, Sales I, Almalag H, Alwhaibi M, Almosabhi L, Albassam AA, Alharbi FA, Bashatah A, Asiri Y. The relationship between health-related quality of life and trust in primary care physicians among patients with diabetes. Clin Epidemiol Epidemiol. 2020;12:143-151. 